\title{
ZAGADNIENIA LINGWISTYCZNE
}

\author{
Łukasz Łukowski*
}

\section{SKUTECZNOŚĆ FORMALNA I MATERIALNA PERFORMATYWU}

Streszczenie. Skuteczność performatywu jest zazwyczaj rozumiana jako spełnienie wszystkich warunków gwarantujących jego poprawną prezentację. Takie podejście jest uzasadnione na gruncie logiczno-filozoficznym. Na gruncie prawoznawstwa wydaje się jednak równie ważne rozważenie innego rodzaju skuteczności performatywu, przyznawanej ze względu na to, czy performatyw faktycznie prowadzi do orzekanej przez siebie zmiany rzeczywistości. Wyróżniona przez Searle'a skuteczność pierwszego rodzaju nazwana jest w pracy formalną, drugiego zaś - materialną. Kombinatoryczne połączenie osiągnięcia bądź nie tych dwóch skuteczności daje cztery przypadki. W warunkach państwa demokratycznego pożądane są przypadki spełnienia materialnego performatywów, które są również spełnione formalnie oraz niespełnienia materialnego performatywów, które nie są także spełnione formalnie. Pozostałe konfiguracje spełnienia performatywów są niepożądane. Jak pokazuje analiza konkretnych przypadków performatywów na gruncie prawa (norm prawnych), prawidłowość ta nie zachodzi w sytuacji, gdy funkcjonowanie demokracji doznaje uszczerbku. Fakt ten stwarza możliwość ,performatywnego” zdefiniowania systemu demokratycznego rozumianego jako państwo prawa.

Słowa kluczowe: performatyw, skuteczność performatywu, teoria aktów mowy.

Jak zauważa Jan Woleński ${ }^{1}$, polska literatura poświęcona performatywom prawniczym jest, pod względem liczebnym, dość skromna. Jeśli idzie o publikacje książkowe, o ile piszący te słowa dobrze się orientuje, istnieje zaledwie jedna pozycja dotycząca tego zagadnienia. Jest to monografia Wojciecha Patryasa zatytułowana Performatywy w prawie, w której autor analizuje jednak performatyw prawny z punktu widzenia jego struktury, a zatem ogranicza się jedynie do perspektywy formalno-logicznej. Problem, czy performatyw jest udany czy też nie, został w tej pozycji pominięty. Niniejszy artykuł ma na celu uwzględnienie

\footnotetext{
* Uniwersytet Łódzki, Wydział Prawa i Administracji, Katedra Prawa Konstytucyjnego.

${ }^{1}$ Z recenzji książki W. Patryasa, Performatywy w prawie, Passat, Poznań 2005.
} 
tego właśnie wątku, zwłaszcza że znacznie ważniejszym zagadnieniem - jak podkreśla John Searle - jest skuteczność performatywu niż jego ewentualna wartość logiczna.

\section{POJĘCIE PERFORMATYWU}

Wypowiedź performatywna jest wypowiedzią o szczególnym charakterze. Ma ona moc zmiany rzeczywistości - innymi słowy, określonej ingerencji w rzeczywistość dokonuje się poprzez wygłoszenie odpowiednich słów składających się na daną wypowiedź ${ }^{1}$. Ponadto istnieje drugi warunek definicyjny performatywu, dość często w literaturze pomijany, według którego nie można przeprowadzić wspomnianej ingerencji w inny sposób niż wypowiadając właśnie te, a nie inne słowa. W filozofii podaje się w wątpliwość konieczność spełnienia tego drugiego warunku, odwołując się do nieformalnego charakteru codziennej komunikacji międzyludzkiej. Wypowiedzi performatywne formułowane są przecież w języku naturalnym i niejednokrotnie przyjmują postać typową dla codziennego komunikowania się, a więc nieformalną, niedookreśloną, sprowadzoną do gestu, a nawet milczenia. Tymczasem, przez wzgląd na formalny charakter czynności prawnych, także tych dokonywanych w formie ustnej, można śmiało postawić tezę, że drugi warunek uznania danej wypowiedzi za performatyw, ma szczególnie doniosłe znaczenie w prawie i to zarówno w jego literze, jak i w praktyce.

John Austin podaje przykłady wypowiedzi performatywnych²:

1. „Biorę tę kobietę za mą prawnie poślubioną małżonkę”.

2. „Przepraszam” - po nadepnięciu komuś na stopę.

3. „Nadaję temu statkowi imię Królowa Elżbieta”.

4. „Obiecuję, że będę na twoim ślubie”.

Powyższe przykłady wypowiedzi dobitnie pokazują, że podstawową rolę $\mathrm{w}$ uczynieniu $\mathrm{z}$ wypowiedzi performatywu odgrywa kontekst. Zarówno żadna z przytoczonych przez Austina wypowiedzi, jak i żadna z wypowiedzi wymaganych prawem dla dokonania jakiejkolwiek czynności prawnej, nie spowoduje ingerencji $\mathrm{w}$ rzeczywistość, jeśli zostanie wygłoszona $\mathrm{w}$ nieodpowiednich warunkach, czyli w nieodpowiednim kontekście. Wystarczy przyjąć, że pierwsza $\mathrm{z}$ zacytowanych wypowiedzi zostanie wygłoszona na przyjęciu jako zainscenizowany żart, aby odmówić tej wypowiedzi performatywnego charakteru. Tak więc na gruncie prawnym rozstrzygająca rola kontekstu jawi się wyjątkowo wyraźnie. Przykładowo, jeżeli dana osoba po sporządzeniu prywatnych notatek napisze na

${ }^{1}$ J. L. Austin, Jak działać stowami, [w:] idem, Mówienie i poznawanie. Rozprawy i wyktady filozoficzne, tt. B. Chwedeńczuk, Wydawnictwo Naukowe PWN, Warszawa 1993, s. 4-7.

2 Ibidem, s. 5. 
tej samej kartce słowa „Klauzula wykonalności w imieniu Rzeczypospolitej Polskiej”, nie oznacza to, iż notatki te staną się tytułem wykonawczym, stanowiącym podstawę do przeprowadzenia egzekucji komorniczej.

Naturalnie kontekst odgrywa niesłychanie ważną rolę w przypadku każdego performatywu, bez względu na to, czy ów performatyw ma charakter prawny czy pozaprawny. Jednakże w przypadku tych drugich istnieje zaskakująco duża dowolność w doborze słów, gestów, zachowań powodujących wykonanie danej czynności przez prezentację performatywu. Klasycznym przykładem czynności wykonywanej w relacjach nieformalnych, w codziennym komunikowaniu się są przeprosiny. Aby zadośćuczynić danej osobie nasze złe, w stosunku do niej, postępowanie, nie musimy koniecznie używać illokucyjnego czasownika „przepraszam". Można użyć aktów mowy alternatywnych względem bazowej wypowiedzi, takich jak chociażby: ,przecież nie wiedziałem, co mówię/robię”, „wybacz mi”, „już się nie gniewaj”, „przecież wiesz, że Cię lubię”, „długo się będziesz dąsać" (w formie pytania). Gdy między dwojgiem ludzi zachodzą relacje rodzinne lub inne, o charakterze ściśle osobistym, dopuszczalne są również przeprosiny w formie niewerbalnej, np. poprzez ucałowanie tej osoby lub wręczenie jej kupionego specjalnie z tej okazji prezentu. Przeprosiny, w pewnych ściśle określonych przypadkach, stanowią również czynność prawną, występującą zarówno w sferze prawa cywilnego, jak i karnego. Na gruncie prawa cywilnego, przeprosiny są w ogólny sposób uregulowane w $§ 1$ art. 24 Kodeksu cywilnego ${ }^{3}$. Przepis ten dopuszcza również, by przeprosiny nastąpiły poprzez złożenie w określonej formie oświadczenia określonej treści. Oznacza to, że ustawa nie uzależnia skuteczności przeprosin od wypowiedzenia ściśle określonej formuły. Ważne jest natomiast, aby formuła ta stanowiła jedną z form usunięcia skutków naruszenia dobra osobistego. Znaczenie tego przepisu, jako normy kodeksowej, uprawnia sądy do zasądzania w procesach cywilnych jako zadośćuczynienia, przeprosin o ściśle określonej sentencją wyroku treści oraz precyzyjnie wskazanego trybu prezentacji tychże przeprosin. Chodzi tu o jednoznaczne wskazanie w sentencji tego środka masowego przekazu, w którym przeprosiny mają być zaprezentowane. Można zatem wysnuć wniosek, iż swoboda językowa performatywu w sferze stosunków prawnych jest dalece ograniczona, zaś granice te wyznaczone są jedynie zasadami swobody decyzyjnej sędziego. Ponadto w przeciwieństwie do zasad przyjętych w relacjach pozaprawnych, w sferze stosunków prawnych mocnemu ograniczeniu ulega również swoboda decyzyjna osoby przepraszanej. W codziennej komunikacji międzyludzkiej przyjęcie przeprosin jest najczęściej arbitralną decyzją adresata przeprosin. Osoba ta, przyjmując przeprosiny lub nie, samodzielnie rozstrzyga, czy przeprosiny odniosą zamierzony przez nadawcę skutek czy też nie. Na gruncie prawnym sytuacja wygląda zgoła inaczej. Osoba, na rzecz której zasądzono przeprosiny, nie ma możliwości nieprzyjęcia przeprosin, gdyż nie ona

\footnotetext{
${ }^{3}$ Ustawa z dnia 23 kwietnia 1964 r. - Kodeks cywilny (t.j. Dz. U. 2014, poz. 121).
} 
jest dysponentem przywrócenia naruszonej równowagi w stosunkach prawnych. Jest to szczególnie jaskrawo widoczne w sytuacji, w której osoba zobowiązana wyrokiem do przeproszenia nie wykonuje nałożonego na nią obowiązku. Osoba poszkodowana działaniem sprawcy ma jedynie możliwość opublikowania przeprosin w określonym przez sąd środku masowego przekazu i obciążenia osoby, przeciwko której wyrok został wydany, kosztami tejże publikacji.

Zasadnicze różnice $\mathrm{w}$ prawnym i pozaprawnym podejściu do spełnienia wspomnianego wyżej drugiego warunku definicji performatywu wynikają z samej specyfiki języka naturalnego. Nasze codzienne komunikowanie się nie ma charakteru formalnego w tym sensie, że znaczenie wypowiedzi nie daje się zredukować do słownikowego znaczenia wypowiedzianych słów, konstytuujących jedynie treść propozycjonalna aktu mowy ${ }^{4}$. Ta nieredukowalność sensu wypowiedzi do rozumienia samej tylko treści propozycjonalnej wynika z faktu, że wypowiadając dokładnie te same słowa, możemy przecież wyrazić zupełnie różne sensy, nawet przeciwne do słownikowych. Przykładowo, gdy wypowiadam zdanie: „Pański poziom intelektualny wzbudza mój szczery zachwyt”, może to wyrażać faktyczny podziw, może również stanowić jawne szyderstwo, jeśli tylko słowa te wypowiem w ironicznym tonie lub w określonej sytuacji, np. wtedy gdy osoba ta przed chwilą ośmieszyła się kompromitującą wypowiedzią. Z drugiej strony zamierzony sens możemy wyrazić, posługując się różnymi zestawami słów. Przywołany już przykład przeprosin pokazuje, że różnymi aktami mowy, nawet takimi, które pozbawione są zwrotów „przepraszam” czy też „wybacz mi”, można osiągnąć cel illokucyjny przepraszania. Elementem aktu illokucyjnego ${ }^{5}$, rozstrzygającym o ostatecznym sensie nadanym w wypowiedzi treści propozycjonalnej, jest tak zwana siła illokucyjna tego aktu.

Pierwszymi dwoma składnikami siły illokucyjnej wypowiedzi są cel illokucyjny, a zatem funkcja komunikacyjna, którą spełniać ma ów akt i stopień natężenia celu ${ }^{6}$. Cel illokucyjny pytania ma dla przykładu realizować wypowiedź „Którego dnia masz zamiar złożyć apelację w sprawie pana N.?”, podczas gdy wypowiedź „Jesteś zobowiązany do spłacania rat kredytu do 10. dnia każdego miesiąca" powinna realizować cel illokucyjny rozkazu. Dwie wypowiedzi posiadające ten sam cel illokucyjny mogą różnić się stopniem natężenia tego celu. Można bowiem prosić o wykonanie pewnej czynności bardziej lub mniej usilnie, można stwierdzić coś bardziej lub mniej dobitnie itd.

Trzecim składnikiem siły illokucyjnej aktu mowy, szczególnie ważnym z prawnego punktu widzenia, jest tryb prezentacji tegoż aktu. Ważność i skutecz-

${ }^{4}$ P. Łukowski, Logika prawnicza z elementami wiedzy o manipulacji, Wolters Kluwer, Warszawa 2012, s. 41.

${ }^{5}$ Akt mowy rozumiany jako akt illokucyjny ma realizować pewną funkcję komunikacyjną.

${ }^{6}$ Zarówno te, jak i inne składniki siły illokucyjnej zostały omówione za: J. R. Searle, D. Vanderveken, Foundations of Illocutionary Logic, Cambridge University Press, Cambridge 1985, s. 12-20. 
ność niektórych aktów illokucyjnych wymaga, aby ich wypowiedzenie miało określoną formę oraz sposób wypowiedzenia uwzględniający również to, kto ten akt wypowiada ${ }^{7}$. Wszystkie te warunki składają się na tryb prezentacji aktu mowy. Przykładów niezastępowalności stosowania tego, a nie innego trybu, dostarcza każda dziedzina prawa. Wydaje się jednak, że w świadomości społecznej najwyraźniej uobecnia się to w prawie konstytucyjnym. Nie licząc aktów prawa miejscowego, aktem prawa powszechnie obowiązującego o najniższej mocy prawnej jest rozporządzenie. Jako akt normatywny o charakterze wykonawczym (w przeważającej większości ${ }^{8}$ akty te wydawane są przez organy egzekutywy) musi on być wydany na podstawie szczegółowego upoważnienia określonego w ustawie i w celu wykonania tejże ustawy. Warunkiem prawidłowości tegoż upoważnienia jest precyzyjne wskazanie organu uprawnionego do wydania rozporządzenia. Organ ten objęty jest na mocy art. 92 ust. 2 Konstytucji RP ${ }^{9}$ tzw. zakazem subdelegacji, który polega na tym, iż podmiot upoważniony do wydania rozporządzenia nie może przekazać tej kompetencji innemu organowi. Przykłady restrykcji przy wydawaniu niektórych rodzajów aktów illokucyjnych znajdujemy również w innych gałęziach prawa. Na gruncie przepisów prawa cywilnego materialnego doskonałym przykładem okazują się przepisy wymagające, dla ważności określonej czynności prawnej, dochowania szczególnej formy. Zwykłą formę czynności prawnej stanowi forma ustna, a oprócz niej Kodeks cywilny przewiduje cztery formy szczególne ${ }^{10}$. Przykładowo, zbycie przedsiębiorstwa wymaga dla swej ważności formy pisemnej z podpisami notarialnie poświadczonymi, zaś klasyczną ilustracją czynności prawnej wymagającej formy aktu notarialnego jest umowa przenosząca własność nieruchomości uregulowana w artykule 158 Kodeksu cywilnego ${ }^{11}$. Przykładem konieczności wypowiedzenia aktu illokucyjnego przez określony podmiot, na gruncie prawnym, jest przymus adwokacko-radcowski. Artykuł $526 \S 2$ Kodeksu postępowania karnego ${ }^{12}$ stanowi, iż kasacja powinna być sporządzona i podpi-

${ }^{7}$ Charakterystyczne dla teorii aktów mowy wyrażenie ,prezentacja aktu mowy” ma szerokie znaczenie. Może ona polegać np. na złożeniu pozwu, ogłoszeniu wyroku, wydaniu pisma, opublikowaniu ustawy w Dzienniku Ustaw.

${ }^{8}$ Organem uprawnionym do wydawania rozporządzeń, a usytuowanym (według ustrojodawcy) poza hierarchią egzekutywy jest Krajowa Rada Radiofonii i Telewizji.

${ }^{9}$ Konstytucja Rzeczypospolitej Polskiej z dnia 2 kwietnia 1997 r. (t.j. Dz. U. 1997, nr 78, poz. 483 ze zm.).

${ }^{10}$ Szczególne formy czynności prawnych stanowią hierarchię, w której forma wyższa czyni zadość niższej. Najniższą rangę spośród owych form posiada pismo zwykłe. Prawo wyróżnia ponadto formę pisemną z urzędowo poświadczoną datą, formę pisemną z podpisami urzędowo poświadczonymi, zaś najwyższą hierarchicznie formę czynności prawnej stanowi akt notarialny.

${ }^{11}$ Aby uniemożliwić obejście formy aktu notarialnego (forma czynności prawnej odpowiada w teorii aktów mowy trybowi prezentacji aktu illokucyjnego), ustawodawca, w tym samym przepisie, przewidział ową formę również dla umowy zobowiązującej do przeniesienia własności nieruchomości.

${ }^{12}$ Ustawa z dnia 6 czerwca 1997 r. - Kodeks postępowania karnego (t.j. Dz. U. 2013, poz. 765). 
sana przez adwokata, o ile nie składa jej prokurator, Prokurator Generalny albo Rzecznik Praw Obywatelskich. Przymus adwokacki obowiązuje w postępowaniu karnym jeszcze w trzech innych przypadkach - przy wniesieniu subsydiarnego aktu oskarżenia (stanowi o tym art. 55 § 2 k.p.k.), przy złożeniu apelacji od wyroku sądu okręgowego (art. $446 \S 1$ k.p.k.) oraz przy składaniu wniosku o wznowienie postępowania (art. $545 \S 2$ k.p.k.). Jego obowiązywanie jest zaś uchylone w sytuacji, gdy którykolwiek z wyżej wymienionych środków prawnych zostaje zastosowany przez prokuratora. Także na gruncie postępowania cywilnego przymus adwokacko-radcowski jest ustanowiony jednym ogólnym przepisem artykułu 87 $\mathrm{z}$ indeksem 1 Kodeksu postępowania cywilnego ${ }^{13}$. Na mocy paragrafu pierwszego tegoż artykułu obowiązkowe zastępstwo wykonywane przez adwokata lub radcę prawnego obejmuje strony występujące przed Sądem Najwyższym oraz czynności procesowe związane z postępowaniem przed tym sądem podejmowane przed sądem niższej instancji. Paragrafy drugi i trzeci artykułu $87 \mathrm{z}$ indeksem 1 uchylają jednak przymus adwokacko-radcowski w postępowaniu o zwolnienie z kosztów sądowych oraz ustanowienie adwokata lub radcy prawnego, a ponadto w sytuacji, gdy stroną, jej organem, przedstawicielem ustawowym lub pełnomocnikiem jest sędzia, prokurator, notariusz albo profesor lub doktor habilitowany nauk prawnych, jak również gdy stroną, jej organem lub przedstawicielem ustawowym jest adwokat, radca prawny lub radca Prokuratorii Generalnej Skarbu Państwa.

Kolejny składnik siły illokucyjnej stanowią warunki treści propozycjonalnej. Narzuca je typ siły illokucyjnej. Na przykład prośba musi odnosić się do wydarzeń przyszłych, zaś żal czy ubolewanie - do zdarzeń przeszłych. Jasnym jest, że wypowiedzeniu odpowiednich słów towarzyszy określony stan psychologiczny. Warunki treści propozycjonalnej stawiają także wymóg przypisania odpowiedzialności danej osobie za wypowiedziane słowa dla skuteczności określonego aktu illokucyjnego. Szczególnie wyraźnie daje się to dostrzec w prawie karnym. Nie można jakiejkolwiek osobie przypisać odpowiedzialności za popełnione przestępstwo, jeżeli którykolwiek z warunków definicji przestępstwa nie został spełniony. Artykuł $1 \S 3$ Kodeksu karnego ${ }^{14}$ wyraźnie stanowi, iż nie popełnia przestępstwa sprawca czynu zabronionego, jeżeli nie można mu przypisać winy w trakcie czynu. Jeżeli zatem przykładowo dana osoba obrazi kogoś werbalnie, a biegły stwierdzi, że w czasie popełnienia czynu jej poczytalność była wyłączona, nie będzie można przypisać jej przestępstwa zniewagi określonego w artykule 216 Kodeksu karnego.

Warunki wstępne, czyli następny rozważany przez Searle'a i Vandervekena składnik siły illokucyjnej, określają, w jakich okolicznościach dany akt illokucyjny można skutecznie wygłosić. Przykładem, na gruncie procedury karnej, może być szczególny przypadek zadania świadkowi pytania. Zgodnie z artykułem 183

${ }^{13}$ Ustawa z dnia 17 listopada 1964 r. - Kodeks postępowania cywilnego (t.j. Dz. U. 2013, poz. 880).

${ }^{14}$ Ustawa z dnia 6 czerwca 1997 r. - Kodeks karny (t.j. Dz. U. 2014, poz. 538). 
$\S 1$ Kodeksu postępowania karnego świadek może uchylić się od odpowiedzi na pytanie, jeżeli udzielenie odpowiedzi mogłoby narazić jego lub osobę dla niego najbliższą na odpowiedzialność za przestępstwo lub przestępstwo skarbowe. Paragraf drugi tegoż artykułu wskazuje, że świadek może żądać, aby przesłuchano go na rozprawie z wyłączeniem jawności, jeżeli treść zeznań mogłaby narazić na hańbę jego lub osobę dla niego najbliższą. Owymi warunkami wstępnymi skutecznego zadania pytania są, według paragrafu 1 - pouczenie o możliwości uchylenia się od odpowiedzi, zaś według paragrafu 2 - pouczenie o możliwości wyłączenia jawności rozprawy. Jeśli idzie o postępowanie cywilne oraz procedurę administracyjną, dobrym przykładem warunków wstępnych prowadzenia egzekucji (czy to administracyjnej, czy to cywilnej) są jej ograniczenia przedmiotowe. Ściślej mówiąc, przepisy te wskazują, z jakich składników mienia dłużnika wierzyciel nie może zostać zaspokojony. Dopiero kiedy warunki wstępne aktu illokucyjnego (w tym przypadku tytułu egzekucyjnego) zostaną spełnione, tj. kiedy komornik odnajdzie w mieniu dłużnika przedmioty nieobjęte katalogiem ograniczeń przedmiotowych, wówczas egzekucja będzie mogła zostać skutecznie przeprowadzona. Ograniczenia przedmiotowe zostały uregulowane w artykułach 829 i 831 k.p.c. w odniesieniu do egzekucji cywilnej oraz w artykułach 8 i 8 a ustawy o postępowaniu egzekucyjnym w administracji, w odniesieniu do egzekucji administracyjnej ${ }^{15}$.

Szósty składnik siły illokucyjnej aktu mowy - warunki szczerości - dotyczy autentyczności przeżywanych przez nadawcę aktów mowy: emocji i stanów psychologicznych. To, z pozoru, zaskakujące przeciwstawienie emocji stanom psychologicznym w teorii aktów mowy ma na celu odróżnienie takich stanów, jak radość, gniew, miłość, nienawiść od zupełnie nieemocjonalnego stanu przekonania co do prawdziwości lub fałszywości określonych sądów. Akt mowy jest zatem niewadliwy ze względu na warunki szczerości, jeśli wyraża emocje lub stan psychologiczny, który faktycznie nadawca tego aktu przeżywa. Innymi słowy, warunki szczerości są spełnione, jeśli sens wypowiedzianych słów jest spójny ze stanem psychologicznym oraz emocjami przeżywanymi przez osobę wypowiadającą te słowa. Na gruncie procesu karnego warunki szczerości siły illokucyjnej aktów mowy możemy badać przede wszystkim w oparciu o analizę prawdomówności świadków zeznających przed sądem. Jeżeli świadek umyślnie dopuszcza się przestępstwa, składania fałszywych zeznań określonego w artykule 233 § 1 Kodeksu karnego czy chociażby tylko zataja pewne fakty z obawy przed zemstą osób, przeciwko którym zeznaje, wówczas akt illokucyjny, jakim są zeznania, jest wadliwy ze względu na niespełnienie warunków szczerości. Naturalnie zróżnicowany może być stopień natężenia warunków szczerości, będący siódmym składnikiem siły illokucyjnej. Jeśli osoba wypowiadająca dane słowa wyrazi swoje emocje lub stan psychologiczny, w takim natężeniu, w jakim faktycznie je przeżywa,

${ }^{15}$ Ustawa z dnia 17 czerwca 1966 r. o postępowaniu egzekucyjnym w administracji (t.j. Dz. U. 2014, poz. 1619). 
wówczas warunek ten należy uznać za spełniony. W sytuacji, gdy dany typ siły illokucyjnej wymaga, aby stan psychologiczny był wyrażony w określonym stopniu natężenia, wówczas ten stopień nazwiemy właściwym (charakterystycznym) stopniem natężenia warunków szczerości $i^{16}$. Dla przykładu, jeżeli ta sama osoba wygłasza dwie wypowiedzi - jedną potępiającą kradzież 50 tysięcy złotych z kasy przedsiębiorstwa oraz drugą, w której gani defraudację kilku miliardów złotych z budżetu państwa i wyraża większe oburzenie pierwszym zdarzeniem aniżeli drugim, możemy mówić o niewłaściwym stopniu natężenia warunków szczerości w przypadku co najmniej jednej z tych wypowiedzi.

Ustawodawca, poprzez formalizm czynności prawnych, próbuje sprowadzić rozumienie aktu mowy jedynie do treści propozycjonalnej. Język prawny, a zatem język aktów prawnych, redukuje znaczenie siły illokucyjnej. Chodzi tu bowiem o możliwie duże ograniczenie spektrum możliwości interpretacyjnych wypowiedzi prawnej. Straciła zatem na aktualności sformułowana przed dziesięcioma laty przez Wojciecha Patryasa teza, według której ani prawodawca, ani prawnicy nie dążą do wyrugowania z przepisów prawnych każdego niejednoznacznego wyrażenia ${ }^{17}$. Obserwując poszczególne nowelizacje, zwłaszcza jeśli idzie o ustawodawstwo karne, można odnieść wrażenie, że do polskiego prawa wkracza, już całkiem otwarcie, kazuistyka. Dlatego też spełnienie warunku drugiego definicji performatywu, gwarantującego niemożność dokonania określonej czynności prawnej w inny sposób niż poprzez wypowiedzenie ściśle określonych słów w ściśle określonych warunkach, staje się w sferze stosunków prawnych koniecznością. Ograniczenie znaczenia siły illokucyjnej prowadzące do zredukowania wypowiedzi jedynie do słownikowego znaczenia wypowiadanych wyrazów sprawia, że podana wcześniej wypowiedź ,już się nie gniewaj”, stanowiąca formę przeprosin w języku codziennej komunikacji, w sferze stosunków prawnych staje się jedynie rozkazem.

\section{WARTOŚĆ WYRÓŻNIONA PERFORMATYWU}

W logice wciąż trwa kilkusetletni, nierozstrzygnięty ostatecznie spór co do tego, czy performatyw posiada wartość logiczną. Odwołując się do omawianego wcześniej przykładu przepraszania, jeżeli dana osoba przeprasza szczerze, wynikałoby z tego, że performatyw posiada wartość logiczną i w tym przypadku jest nią

${ }^{16}$ P. Łukowski, Konceptualizacja kłamstwa i manipulacji $w$ teorii aktów mowy Searle'aVandervekena, [w:] P. Stalmaszczyk (red.), Studia z metodologii i filozofi językoznawstwa. Od zdań do aktów mowy. Analizy językoznawcze i filozoficzne, Wydawnictwo Uniwersytetu Lódzkiego, Łódź 2015, s. 168.

17 W. Patryas, op. cit., s. 160. 
wartość logiczna prawdy. Zmieniając świat, performatyw faktycznie o tej zmianie orzeka. Istnieje zatem uzasadniona pokusa uogólnienia, iż każdy performatyw dokonujący rzeczywistej zmiany w rzeczywistości, o której orzeka, ma wartość logiczną prawdy. Jaką jednak wartość logiczną należy przypisać performatywowi wadliwie wyrażonemu, np. kiedy osoba wypowiadająca słowo „przepraszam” w rzeczywistości nie chce przeprosić, bo np. nie czuje się winna; kiedy ktoś mówiąc, że daruje komuś winę, faktycznie w duchu przysięga zemstę? Czy wówczas mamy do czynienia z performatywem fałszywym? Problem ten trudno jednoznacznie rozstrzygnąć. Wydaje się jednak, że w sferze stosunków prawnych ewentualna wartość logiczna performatywu nie odgrywa istotnej roli. Jakie bowiem prawne znaczenie może mieć fakt, iż osoba zobowiązana do ogłoszenia przeprosin w mediach czyni to nieszczerze? Prawdę mówiąc, to wątpliwe znaczenie posiadania wartości logicznej ma każdy performatyw, nie tylko prawniczy. W pismach Austina, Searle'a i Vandervekena wyraźnie widać, że kluczowym aspektem oceny performatywu nie jest jego ewentualna wartość logiczna, lecz to, czy faktycznie jego wygłoszenie skutkuje zamierzoną zmianą rzeczywistości. Innymi słowy, nie tyle ważne jest rozpoznanie wartości logicznej performatywu - jeśli taką w ogóle posiada - ile rozpoznanie, czy jest on performatywem udanym (skutecznym) czy też nie. Takie też stanowisko zostało przyjęte w niniejszej pracy. Oznacza to, że wartością wyróżnioną performatywu jest dla nas jego skuteczność, a nie prawdziwość.

W literaturze przedmiotu wskazuje się na istnienie celów - bezpośredniego oraz finalnego - aktu mowy ${ }^{18}$. Pierwszy z nich jest osiągnięty wówczas, gdy spełnione są warunki opisujące wymienione powyżej siedem składników siły illokucyjnej. Jednak udana prezentacja aktu mowy nie oznacza, iż zamierzony przez nadawcę tego aktu efekt perlokucyjny ${ }^{19}$ zostaje osiągnięty. Akt mowy nie jest bowiem wygłoszony dla samego wygłoszenia, lecz aby osiągnąć inny cel, określany mianem celu finalnego. To odróżnienie celu bezpośredniego od finalnego, a zatem skuteczności bezpośredniej od finalnej, jest szczególnie ważne w przypadku tych aktów mowy, które są performatywami. Zatem to czy performatyw jest udany, należy rozważyć z dwóch perspektyw. Pierwszą jest formalna poprawność performatywu, drugą zaś - materialna, która zachodzi, wówczas gdy zaistnieje wyrażona performatywem zmiana rzeczywistości. Czym innym jest więc skuteczność performatywu polegająca na tym, iż jego wypowiedzenie jest udane (niewadliwe), czym innym zaś to, czy pociąga on za sobą zamierzoną zmianę w świecie. Podchodząc do problemu kombinatorycznie, powinniśmy wyróżnić cztery możliwe przypadki skuteczności performatywu:

1. Niewadliwy performatyw wywołuje deklarowaną zmianę w świecie;

2. Niewadliwy performatyw nie wywołuje deklarowanej zmiany w świecie;

${ }_{18}$ M. Nowak, Formalna reprezentacja pojęcia sądu dla zastosowań w teorii aktów mowy, Wydawnictwo Uniwersytetu Łódzkiego, Łódź 2003, s. 51-52.

${ }^{19}$ Czyli wywołanie u odbiorcy określonej reakcji. 
3. Wadliwy performatyw wywołuje deklarowaną zmianę w świecie;

4. Wadliwy performatyw nie wywołuje deklarowanej zmiany w świecie.

Chciałoby się, aby w rzeczywistości zachodziły jedynie przypadki pierwszy i czwarty. Z teoretycznego punktu widzenia, w warunkach państwa demokratycznego, rozumianego nie tylko z punktu widzenia rządów większości, lecz także jako państwa rządzącego się prawem pisanym, tak właśnie być powinno. Niestety, niejednokrotnie realizują się jednak pozostałe dwa przypadki. Z powyższych powodów analiza kategorii performatywu została podzielona na przypadki pożądane, a więc pierwszy i czwarty oraz przypadki niepożądane, tj. drugi i trzeci.

\section{PERFORMATYWNA ANALIZA DEMOKRATYCZNEGO CHARAKTERU PAŃSTWA}

Przypadek pierwszy występuje, gdy niewadliwy performatyw wywołuje pożądaną zmianę w świecie. Może się wydawać, że z punktu widzenia stosowania prawa sytuacja ta jest ze wszech miar właściwa. Staje się bowiem sygnałem, jaki państwo wysyła do obywateli, dowodzącym, iż uchwalone prawo obowiązuje, a nieuchwalone - nie obowiązuje. Wówczas w świadomości obywateli rodzi się uzasadnione przekonanie, że państwo funkcjonuje sprawnie. Na gruncie systemu prawa oznacza to, że zarówno obowiązujące procedury stanowienia prawa są skrupulatnie przestrzegane (poprawność formalna), jak i to, że uchwalone prawo jest bezwzględnie egzekwowane (poprawność materialna). Może się też wydawać, że podobnie pożądany i potrzebny jest przypadek czwarty, gdy wadliwy performatyw nie wywołuje deklarowanej zmiany w świecie. Uzasadnienie dla tego przypuszczenia jest dokładnie takie, jak dla przypadku pierwszego. Niepoprawność formalna performatywu oznacza bowiem, że procedury stanowienia prawa nie zostały dochowane, a w konsekwencji prawo takie nie obowiązuje. W polskim systemie prawnym funkcję strażnika poprawności formalnej aktów prawnych pełni Trybunał Konstytucyjny.

$\mathrm{Na}$ gruncie prawnym druga z przedstawionych sytuacji, a zatem ta, w której niewadliwy performatyw nie wywołuje deklarowanej zmiany w świecie, zdarza się stosunkowo rzadko. W państwie demokratycznym tego typu sytuacja wydaje się wręcz nie do pomyślenia. Jednak na przykład w polskim prawie istnieją przepisy, których dyspozycji organy państwa uporczywie nie stosują. Zalicza się do nich m.in. artykuł $370 \S 1$ Kodeksu postępowania karnego ${ }^{20}$, który stanowi

${ }^{20}$ Dnia 1 lipca 2015 r. weszła w życie nowelizacja Kodeksu postępowania karnego wprowadzająca szereg przepisów mających jakoby ustanawiać kontradyktoryjność procesu karnego. Ostatnie zdanie paragrafu pierwszego artykułu 167 k.p.k. dopuszcza jednak możliwość przeprowadzenia przez sąd dowodu z urzędu, co stanowi zdecydowane przełamanie na rzecz dotychczas funkcjonującej inkwizycyjności procesu karnego. 
o kolejności zadawania pytań osobie przesłuchiwanej przez poszczególne podmioty procesu. Według powyższego przepisu mogą zadawać jej pytania w następującym porządku: oskarżyciel publiczny, oskarżyciel posiłkowy, pełnomocnik oskarżyciela posiłkowego, oskarżyciel prywatny, pełnomocnik oskarżyciela prywatnego, powód cywilny, pełnomocnik powoda cywilnego, biegły, podmiot, o którym mowa w art. 416 (zobowiązany do zwrotu uzyskanej korzyści majątkowej pochodzącej z przestępstwa), obrońca, oskarżony, członkowie składu orzekającego. W praktyce sytuacja wygląda w ten sposób, że prokurator obecny na rozprawie najczęściej (jest to zasadą w rozprawach przed sądami rejonowymi) nie prowadzi sprawy od samego początku, zaś jego udział jest skutkiem przydzielenia mu, na dzień przeprowadzenia rozprawy, dyżuru w sądzie. Można zatem stwierdzić, że wybór prokuratora ma charakter losowy. Bardzo często zdarza się również, że mającego pełnić funkcję obrońcy adwokata w procesie karnym zastępują jego aplikanci, którzy, podobnie jak prokurator, nie są zmuszeni orientować się w meandrach sprawy. Praktyka przesłuchania wygląda zatem w ten sposób, że większość kwestii budzących wątpliwości jest wyjaśniana podczas przesłuchania danej osoby przez członków składu orzekającego, a stricte sędziów, którzy to jako pierwsi zadają pytania osobie przesłuchiwanej. Pomimo przytoczonego brzmienia przepisu artykułu $370 \S 1$ k.p.k. przesłuchanie zatem jest de facto przeprowadzane przez sąd, a jeśliby pozostały jeszcze jakiekolwiek kwestie budzące wątpliwości, wówczas najczęściej osoba przesłuchiwana wyjaśnia je na skutek pytań samego oskarżonego i niekiedy również obrońcy. Podobnie ma się przepis artykułu 62 Kodeksu karnego stanowiący o tym, iż sąd może przy orzekaniu kary pozbawienia wolności określić rodzaj i typ zakładu karnego, w którym skazany ma odbywać karę, a także orzec system terapeutyczny jej wykonania. Przepełnienie zakładów karnych nie tylko uniemożliwia sędziemu przeprowadzenie należytej oceny danego zakładu karnego pod kątem osadzenia w nim skazanego, lecz nierzadko także uniemożliwia natychmiastowe wykonanie kary. Widzimy zatem wyraźny rozdźwięk pomiędzy niewadliwością uchwalonego performatywu a brakiem zmiany w rzeczywistości, która to zmiana powinna być wywołana na skutek wygłoszenia owego performatywu.

Tak jak przypadek pierwszy i czwarty są ze sobą skorelowane w tym sensie, że uzasadnienie pierwszego jest zarazem uzasadnieniem czwartego, tak również daleko idącą korelację wykazują przypadki drugi i trzeci, gdy wadliwy formalnie performatyw wywołuje deklarowaną zmianę. Podany wyżej przykład uporczywego niestosowania przepisu o kolejności zadawania pytań osobie przesłuchiwanej ilustruje przecież również przypadek obowiązywania nieobowiązującego prawa. Zostaje ono wprowadzone wyłącznie na skutek długotrwałej praktyki. Podobny charakter nieobowiązującego prawa ma pomijanie drugiego $\mathrm{z}$ analizowanych przepisów (artykuł 62 k.k.). Proste utożsamienie przypadku drugiego z trzecim byłoby błędem. Istnieją bowiem sytuacje, które ilustrując przypadek trzeci, nie ilustrują drugiego. Zdarza się, że zdobyta demokratycznie władza funkcjonuje 
w rzeczywistości, w której media głównego nurtu wbrew swej misji nie wykonują powierzonego im zadania kontrolowania władzy. W sytuacji takiej władza się degeneruje, dopuszczając się korupcji, marnotrawienia publicznych pieniędzy, arogancji i innych patologii. Nieuchronnie sytuacja ta prowadzi do niezadowolenia społecznego, które może przyjąć takie rozmiary, iż legalnie wybrana władza zostaje obalona przy pomocy kryterium ulicznego. $Z$ formalnego punktu widzenia społeczeństwo nie ma prawa przerwać kadencji jakiegokolwiek organu ${ }^{21}$, chodzi jedynie o wywarcie moralnego nacisku na osoby pełniące najwyższe funkcje w państwie, dlatego też w takiej sytuacji wymuszona naciskiem społecznym dymisja któregokolwiek z organów jest performatywem formalnie wadliwym, materialnie zaś skutecznym. Powyższy schemat realizuje się od czasu do czasu w niektórych krajach Europy Środkowo-Wschodniej - w Gruzji w 2003 r., na Ukrainie w roku 2004, w Kirgistanie w roku 2005 i ponownie na Ukrainie w roku 2014.

Analizy pokazujące, iż przypadki pierwszy i czwarty są pożądanymi, zaś drugi i trzeci - niepożądanymi, przyjmują jedno ważne, choć niewypowiedziane do tej pory, założenie. Jest nim demokratyczny charakter ustroju państwa. W sytuacji, kiedy to założenie nie jest spełnione, trudno jest jakąkolwiek konfigurację skuteczności formalnej i materialnej performatywu oceniać jako pożądaną lub niepożądaną. Ostatni z przykładów, ilustrujący przypadek trzeci, sygnalizuje tę prawdę. Degeneracja władzy przejawiająca się w korupcji, kłamstwach medialnych i arogancji jest możliwa tylko w systemie, w którym demokracja przestaje funkcjonować. Zatem performatyw sankcjonujący obalenie takiej władzy powinien być wartościowany pozytywnie, mimo iż ilustruje przypadek trzeci. W podobny sposób można pokazać możliwość odwrotnego wartościowania pozostałych przypadków. I tak, wydawać by się mogło, wyłącznie pozytywny przypadek pierwszy miał przecież w historii swoją niechlubną, a nawet i zbrodniczą realizację. Taka sytuacja miała jednak miejsce w III Rzeszy Niemieckiej, kiedy 15 września 1935 r. Reichstag uchwalił tzw. ustawy norymberskie, pozbawiające niemieckich Żydów obywatelstwa niemieckiego, ochrony prawnej oraz własności. Te i inne haniebne akty prawne, mimo swej formalnej i materialnej skuteczności, mają dziś jednoznacznie negatywną ocenę. Przy okazji warto nadmienić, że przypadek ten stał się podstawą krytyki pozytywizmu prawniczego oraz przyjęcia i stosowania formuly Radbrucha. Innym niechlubnym przykładem, który tym razem ilustruje wydawać by się mogło wyłącznie pozytywny przypadek czwarty, okazuje się Konstytucja Polskiej Rzeczypospolitej Ludowej z 22 lipca $1952 \mathrm{r}^{22}$ Akt ten był nieskuteczny zarówno formalnie, jak i materialnie. Po opracowaniu projektu ustawy zasadniczej został przedstawiony do zatwierdzenia Józefowi Stalinowi, a zatem przywódcy obcego państwa, jakim

${ }^{21}$ Zachowanie takie, pod warunkiem użycia przemocy, jest wręcz spenalizowane w artykule 128 Kodeksu karnego.

${ }^{22}$ Konstytucja Polskiej Rzeczypospolitej Ludowej z 22 lipca 1952 r. (t.j. Dz. U. 1976, nr 7 , poz. 36). 
był przecież Związek Socjalistycznych Republik Radzieckich - nieskuteczność formalna. Przykład ten bardzo wyraźnie pokazuje, w jaki sposób kluczowy z punktu widzenia funkcjonowania państwa akt normatywny wchodzi w życie pomimo niewątpliwie wadliwej procedury jego uchwalenia. Co zaś się tyczy samej treści konstytucji, to ustrój nią kreowany miał charakter jednoznacznie demokratyczny, paradoksalnie tracąc pewne cechy demokratyczności po nowelizacji z 1976 r. konstytuującej wieczysty sojusz z ZSRR i przewodnią rolę Polskiej Zjednoczonej Partii Robotniczej. Pomijając ten późniejszy zapis, przyjmuje się dość zgodnie, iż konstytucja ta w pozostałych częściach prezentowała rzeczywistość demokratyczną, która w rzeczywistości nie obowiązywała - nieskuteczność materialna.

W przypadku drugim, na pozór negatywnym, także trudno jest mówić o jednoznacznej ocenie. W historii PRL-u mamy liczne przykłady opozycjonistów skazanych prawomocnymi wyrokami na kary pozbawienia wolności, które to wyroki skazani mogli nieformalnie zamienić na wyjazd zagraniczny na pobyt stały do krajów zachodnich. Naturalnie, przypadek drugi można ilustrować performatywami niepożądanymi, kiedy to korzystny dla opozycjonisty wyrok nie był egzekwowany. Podobnie jest z przypadkiem trzecim, który w rzeczywistości niedemokratycznej można zilustrować przykładami zarówno pożądanych, jak i niepożądanych performatywów. Do niepożądanych należą wyroki sądowe zapadające na „wrogów ludu” w nieuczciwych, a więc nieskutecznych formalnie procesach, które jednak okazywały się materialne skuteczne, gdyż ludzie ci odbywali kary wieloletniego pozbawienia wolności. Innym godnym potępienia performatywem tego typu są dekrety o stanie wojennym z $1981 \mathrm{r}$. Stan wojenny został wprowadzony z naruszeniem obowiązującego wówczas prawa, w co najmniej dwóch obszarach. Po pierwsze, aktami ustanawiającymi stan wojenny były dekrety Rady Państwa $^{23}$. Konstytucja PRL dopuszczała wydawanie przez Radę Państwa ${ }^{24}$ dekretów tylko i wyłącznie pomiędzy sesjami Sejmu, zaś w grudniu 1981 r. Sejm obradował, a zatem sesja była otwarta. Ponadto dekrety te opublikowano dopiero dnia następnego - 14 grudnia. Została zatem naruszona fundamentalna zasada niedziałania prawa wstecz - lex retro non agit. Dostrzec zatem można, iż nie tylko $\mathrm{w}$ teorii możemy mieć do czynienia z rozbieżnościami między prawidłowością wydania określonego aktu prawnego a rzeczywistym wpływem, jaki wywiera on na sytuację prawną określonych podmiotów. W tym przypadku mieszczą się także performatywy jak najbardziej pożądane. Przykład ten został już wcześniej zaprezentowany, zalicza się do niego kolorowa rewolucja.

${ }^{23}$ Dekret o stanie wojennym z dnia 12 grudnia 1981 r. (Dz. U. 1981, nr 29, poz. 154), Dekret o postępowaniach szczególnych w sprawach o przestępstwa i wykroczenia w czasie obowiązywania stanu wojennego z dnia 12 grudnia 1981 r. (Dz. U. 1981, nr 29, poz. 156), Dekret o przekazaniu do właściwości sądów wojskowych spraw o niektóre przestępstwa oraz o zmianie ustroju sądów wojskowych i wojskowych jednostek organizacyjnych Prokuratury Polskiej Rzeczypospolitej Ludowej w czasie obowiązywania stanu wojennego z dnia 12 grudnia 1981 r. (Dz. U. 1981, nr 29, poz. 157).

${ }^{24}$ Organ ten stanowił, w warunkach PRL, kolegialną głowę państwa. 
W wielu państwach, nie tylko demokratycznych, poza prawem pisanym obowiązuje jeszcze jeden system normatywny - prawo zwyczajowe, które zbudowane jest $\mathrm{z}$ norm trwałych i jednolicie wykonywanych w przeświadczeniu, że są obowiązującym prawem. Wydawać by się mogło, że i one, jako swoistego rodzaju performatywy, mają swój wpływ na uznanie danego państwa za demokratyczne. Tak jednak nie jest. Normy prawa zwyczajowego jakkolwiek uznawane za obowiązujące i szanowane, nie są zaliczane do prawa powszechnie obowiązującego. Co za tym idzie, ich naruszenie nie jest obwarowane jakąkolwiek sankcją. Przykładem tego typu normy na gruncie systemu prawa jest ta, według której Prezydent Rzeczypospolitej Polskiej desygnuje na urząd Prezesa Rady Ministrów osobę wskazaną przez większość parlamentarną (gdy następuje to bezpośrednio po wyborach parlamentarnych jest to najczęściej lider zwycięskiej partii politycznej). W sytuacji powierzenia misji tworzenia rządu innej osobie, wybranej wyłącznie przez siebie, Prezydent nie będzie winny deliktu konstytucyjnego. Jest natomiast bardzo prawdopodobne, że osoba ta nawet $\mathrm{w}$ sytuacji sformowania przez siebie gabinetu nie uzyska wotum zaufania niezbędnego dla funkcjonowania Rady Ministrów, a udzielanego przez większość sejmową. Może również dojść, od strony praktycznej, do konfliktu pomiędzy Prezydentem a Sejmem, ale $\mathrm{z}$ uwagi na fakt, iż oba te organy wybierane są w wyborach powszechnych, nie będzie to miało najmniejszego wpływu na ustrój państwa. O uznaniu danego organizmu państwowego za demokratyczny decyduje więc wyłącznie skuteczność norm prawa pisanego.

\section{PODSUMOWANIE}

Wszelkie próby analiz prowadzących do ustalenia prawidłowości o charakterze strukturalnym są możliwe dzięki przyjętym bardzo często w niemy sposób założeniom, tzw. entymematom ${ }^{25}$. Standardowo, w logikach formalnych, analizując poprawność reguł, które prowadzą od zdań prawdziwych do prawdziwych lub od fałszywych do fałszywych, w zależności od rodzaju logiki, przyjmuje się, iż uznane za prawdziwe przesłanki faktycznie są traktowane jak prawdziwe, a uznane za fałszywe traktowane są jako fałszywe. Tym samym w standardowych formalno-logicznych analizach nie uwzględnia się, a nawet nie dopuszcza możliwości kłamania. Uwzględnienie kłamania czyniłoby niemożliwym ustalenia jakichkolwiek reguł rozumowania. Podobną własność można dostrzec w powyższych analizach. Przypadki: zarówno pierwszy - performatywów skutecznych

${ }^{25}$ Przesłanka użyta w rozumowaniu, która jawnie nie została wypowiedziana z powodu swojej oczywistości, zob. P. Łukowski, Logika praktyczna z elementami wiedzy o manipulacji, Wolters Kluwer, Warszawa 2012, s. 221, 250-251. 
zarazem formalnie i materialnie, jak i czwarty - nieskutecznych zarazem formalnie i materialnie, można uznać za wyłącznie pożądane, czyli wartościowane pozytywnie, tylko wówczas, gdy przyjmiemy, iż są one elementem rzeczywistości demokratycznej. Podobną prawidłowość można zaobserwować w przypadkach drugim i trzecim performatywów, a więc odpowiednio performatywów zarazem skutecznych formalnie i nieskutecznych materialnie oraz nieskutecznych formalnie i skutecznych materialnie. Kontekst demokratyczny czyni z nich wyłącznie przypadki niepożądane. Wystarczy jednak, aby rzeczywistość prawna okazała się niedemokratyczna, choćby w najmniejszym stopniu (np. przypadek degenerującej się demokratycznie wybranej władzy), aby trudno było mówić o wskazanych wyżej prawidłowościach. Wniosek ten można odwrócić, formułując definicję państwa demokratycznego. Otóż, gdy klasą performatywów pożądanych jest suma performatywów przypadku pierwszego i czwartego, możemy mówić o demokratycznym państwie prawa. Oznacza to, że klasą performatywów niepożądanych są performatywy klasy drugiej i trzeciej. W dualny sposób można zdefiniować państwo funkcjonujące niedemokratycznie.

\section{BIBLIOGRAFIA}

Austin John Langshaw. 1993. Mówienie i poznawanie. Rozprawy i wykłady filozoficzne. tł. Chwedeńczuk Bohdan. Warszawa: PWN.

Łukowski Piotr. 2012. Logika prawnicza z elementami wiedzy o manipulacji. Warszawa: Wolters Kluwer.

Nowak Marek. 2002. Formalna reprezentacja pojęcia sądu dla zastosowań w teorii aktów mowy. Łódź: Wydawnictwo Uniwersytetu Łódzkiego.

Patryas Wojciech. 2005. Performatywy w prawie. Poznań: Passat.

Searle John Rogers, Vanderveken Daniel. 1985. Foundations of Illocutionary Logic. Cambridge: Cambridge University Press.

Stalmaszczyk Piotr. 2015. Studia z metodologii i filozofii językoznawstwa. Od zdań do aktów mowy. Analizy językoznawcze i filozoficzne. Łódź: Wydawnictwo Uniwersytetu Łódzkiego.

\section{Łukasz Łukowski}

\section{FORMAL AND MATERIAL EFFECTIVENESS OF THE PERFORMATIVE}

\footnotetext{
Abstract. Effectiveness of the performative is usually understood as fulfillment of all the conditions ensuring its proper presentation. This approach is justified on the logical and philosophical basis. On the basis of jurisprudence it seems to be equally important to consider another kind of performative effectiveness which is granted irrespectively of the fact that the performative actually
} 
leads to predicate its reality changes. The first type of the effectiveness distinguished by Searle is called in this work formal effectiveness while the second type - material. Combinatorial connection of achieving or not these two kinds of effectiveness gives four cases. In a democratic state there are cases that meet the desired material performatives, which are also met formally, and non-compliance of the material performatives, which are also not formally met. Other configurations to meet performatives are undesirable. As the analysis of specific cases of performatives in the matter of law (legal norms) shows, this regularity does not occur when the functioning of democracy suffers. This fact implies a possibility of „performative” definition of a democratic system, understood as the rule of law.

Keywords: performative, effectiveness of performative, theory of speech acts. 